\title{
Studi Penggunaan Bahan Aditif Dan Variasi Dosis Accelerator Terhadap Perkerasan Beton Yang Dipercepat (Studi Kasus Mutu Beton K-300)
}

\author{
Suhaimi $^{1}$; R. Dedi Iman Kurnia ${ }^{2}$ \\ ${ }^{12}$ Dosen Program Studi Teknik Sipil Fakultas Teknik Universitas Almuslim \\ Email: adenrestoration@gmail.com, suhaimi_civil@yahoo.com
}

Diterima 10 Juni 2021/Disetujui 24 Juni 2021

\begin{abstract}
ABSTRAK
Penelitian ini bertujuan untuk mengetahui hasil pengujian kuat tekan awal beton kombinasi sikafume (mineral additive) dan variasi dosis penggunaan accelerator (chemical admixture). Penelitian ini menggunakan metode eksperimental. Adapun prosedur penelitian dimulai dengan studi literatur, dilanjutkan dengan persiapan material, pemeriksaan sifat fisis agregat, perencanaan campuran beton (concrete mix design), pembuatan dan perawatan benda uji, serta pengujian benda uji berupa pengujian slump dan pengujian kuat tekan serta analisis data. Berdasarkan hasil dan pembahasan penelitian terkait dengan nilai kuat tekan beton, maupun bentuk atau workability dan waktu perkerasan adalah sebagai berikut: 1) hasil uji kuat tekan beton kombinasi sikafume dengan variasi dosis penggunaan accelerator 1:2 memiliki nilai kuat tekan rata-rata sebesar 26,823 Mpa dan 31,280 Mpa untuk umur pengujian 24 dan 72 jam; 2) hasil uji kuat tekan beton kombinasi sikafume dengan variasi dosis penggunaan accelerator 1:3,5 memiliki nilai kuat tekan rata-rata sebesar 24,913 Mpa dan 30,643 Mpa untuk umur pengujian 24 dan 72 jam; 3) hasil uji kuat tekan beton kombinasi sikafume dengan variasi dosis penggunaan accelerator 1:5 memiliki nilai kuat tekan rata-rata sebesar 23,640 Mpa dan 30,325 Mpa untuk umur pengujian 24 dan 72 jam; 4) nilai slump yang diperoleh pada setiap variasi benda uji lebih besar dari yang direncanakan dalam mix design, yaitu nilai slump yang diperoleh termasuk katagori slump runtuh; dan 5) kombinasi sikafume dan variasi dosis accelerator dapat mempercepat waktu perkerasan dengan nilai kuat tekan rata-rata di atas 24,90 Mpa atau K-300 dalam waktu 24 dan 72 jam.
\end{abstract}

Kata kunci: accelerator, beton, kuat tekan awal, mineral additive, sikafume, waktu pengerasan

\section{PENDAHULUAN}

Kualitas dari pekerjaan konstruksi bangunan dan penyelesaian pekerjaan yang tepat waktu sering kali menjadi momok bagi sebagian besar pelaksanaan konstruksi. Pekerjaan struktur memiliki bobot persentase yang paling besar dari seluruh pekerjaan konstruksi, apalagi konstruksi tersebut merupakan bangunan berlantai banyak. Waktu yang dibutuhkan untuk menyelesaikan komponen struktur sangat menentukan waktu penyelesaian keseluruhan konstruksi.

Aplikasi beton bertulang sebagai material komponen struktur bangunan telah umum digunakan. Beton memiliki kekuatan dan sifat yang baik sebagai bahan struktur bangunan. Secara normal, beton dengan mutu struktural membutuhkan waktu perkerasaan selama 28 hari. Sebelum mencapai mutu rencana sedapat mungkin beton struktural dihindarkan dari pembebanan. Perlu adanya aplikasi teknologi dan modifikasi bahan bangunan yang dapat menyelasaikan permasalahan terkait waktu perkerasaan beton, salah satu cara yang dapat ditempuh adalah penggunaan bahan additive dan accelerator.

Silicafume merupakan hasil produk sampingan dari reduksi quarsa murni ( $\mathrm{SiO} 2)$ dengan batu bara dalam pembuatan campuran silikon dan ferrosilikon. Silicafume mengandung kadar $\mathrm{SiO}_{2}$ yang tinggi. Secara geometrikal, silicafume mengisi rongga-rongga butiran semen (grain of cement). Penggunaan silicafume mengakibatkan diameter pori mengecil serta total volume pori berkurang, Subakti (1995). Accelerator adalah bahan untuk mempercepat peningkatan kekuatan beton, pengaruh yang menguntungkan dari accelerator adalah dapat dimanfaatkan pada beton yang membutuhkan pengerasan yang cepat (Murdock., Brook, 1999). 
Penelitian ini dilakukan terhadap beton bernilai FAS 0,45 dengan penambahan bahan additive berupa silicafume dengan persentase $20 \%$ dari berat semen. Adapun dalam penelitian ini dilakukan variasi terhadap dosis penggunaan bahan accelerator untuk mendapatkan kuat tekan yang paling baik dengan waktu perkerasan yang paling cepat.

\section{METODE PENELITIAN}

Penelitian ini menggunakan metode eksperimental. Adapun prosedur penelitian dimulai dengan studi literatur, dilanjutkan dengan persiapan material, pemeriksaan sifat fisis agregat, perencanaan campuran beton (concrete mix design), pembuatan dan perawatan benda uji, serta pengujian benda uji dan analisis data. Berikut dijabarkan tentang tahapan penelitian, berupa:

1. Pemeriksaan sifat fisis agreat

Setelah mempersiapkan bahan-bahan campuran beton, dilakukan pemeriksaan terhadap material untuk mengevaluasi bahan campuran beton apakah dalam kondisi baik atau layak digunakan sebagai bahan campuran beton. Beberapa pemeriksaan material yang dilakukan, yaitu pemeriksaan kandungan zat organis dalam pasir (ASTMC-40), analisis saringan agregat kasar dan agregat halus (ASTMC-136), pemeriksaan berat jenis dan penyerapan agregat halus dan agregat kasar (ASTMC128 \& ASTMC-127), dan pemeriksaan berat volume agregat kasar dan agregat halus (ASTMC-29);

2. Perencanaan komposisi campuran

Perencanaan komposisi campuran untuk benda uji didasarkan pada perbandingan berat, dengan metode ACI211.4R. Persentase penambahan sikafume yang digunakan adalah $20 \%$ dari berat total semen. Perencanaan campuran beton dilakukan untuk mutu k-300, dengan nilai FAS sebesar 0,45. Perancangan campuran beton menggunakan metode ACI211.4R. Benda uji dibuat dengan faktor air semen (FAS) 0,45 .

Tabel 1. Hasil Perhitungan Perencanaan Campuran Beton K-300 untuk $1 \mathrm{~m}^{3}$

\begin{tabular}{|c|l|c|c|c|c|}
\hline \multirow{2}{*}{ No. } & \multirow{2}{*}{ Material } & \multicolumn{4}{c|}{ Komposisi Campuran K-300 } \\
\cline { 3 - 5 } & & Berat & Satuan & Rasio Berat & Rasio Volume \\
\hline 1 & Air & 186,76 & $\mathrm{Kg}$ & 0,45 & 0,45 \\
\hline 2 & Semen Portland & 415,02 & $\mathrm{Kg}$ & 1,0 & 1,00 \\
\hline 3 & Split & 1040,41 & $\mathrm{Kg}$ & 2,5 & 2,21 \\
\hline 4 & Pasir & 753,40 & $\mathrm{Kg}$ & 1,8 & 1,74 \\
\hline 5 & Sikafume & 83,00 & $\mathrm{Kg}$ & - & - \\
\hline$\Sigma$ & \multicolumn{2}{|c|}{ FAS (Faktor Air Semen) } \\
\hline
\end{tabular}

3. Pembuatan benda uji

Sebelum perencanaan campuran bahan tambah beton berdasarkan yang telah ada pada brosur, diameter maksimum agregat yang digunakan adalah 19,1 mm. Penggunaan sikafume sesuai dengan perencanaan campuran beton yaitu $20 \%$ dari berat semen dan penggunaan accelerator dengan variasi 1:2, 1:3,5 dan 1:5 dari berat air.Pengadukan beton dilakukan dengan memasukkan material pembentuk beton yaitu pasir, batu pecah, semen, sikafume, air dan accelerator secara berturut-turut ke dalam molen. Setelah semua material masuk, dilakukan pengadukan sekitar 5 menit dengan kemiringan sumbu molen $45^{\circ}$. Setelah material teraduk rata, lalu beton yang dihasilkan dituang dalam wadah penampungan beton dan dilakukan pemeriksaan terhadap beton.

Pembuatan benda uji dilakukan dengan mengisi beton segar ke dalam cetakan secara betahap dalam tiga lapisan, dan setiap lapisan mempunyai volume yang sama. Lalu, setiap lapisan dipadatkan dengan tongkat pemadat sebanyak 25 kali tumbukkan, lalu disekeliling dinding cetakan dipukul dengan palu karet agar beton menjadi lebih padat. Pemberian kode benda uji berupa BSF IA, BSF IIA dan BSF IIIA dimaksudkan sebagai variasi dosis perbandingan accelerator dengan air. Maka, kode BSF IA dimaksudkan untuk variasi accelerator dengan air sebesar 1:2, kode BSF 
IIA untuk variasi accelerator dengan air 1:3,5 dan kode BSF IIIA untuk variasi accelerator dengan air 1:5. Untuk penggunaan angka 1 dan 2 di akhir kode benda uji dimaksudkan sebagai variasi umur pengujian kuat tekan beton, yaitu angka 1 dimaksudkan untuk umur pengujian kuat tekan 24 jam sementara angka 2 untuk umur pengujian kuat tekan 72 jam.

Tabel 2. Variasi dan Jumlah Benda Uji

\begin{tabular}{|c|c|c|c|c|}
\hline No. & Kode Benda Uji & & Variabel & $\begin{array}{c}\text { Umur } \\
\text { Pengujian }\end{array}$ \\
\hline 1 & BSF IA1 & Benda uji beton kombinasi & accelerator $1: 2$ + sikafume 24 jam & 24 jam \\
\hline 2 & BSF IA2 & Benda uji beton kombinasi & accelerator $1: 2$ + sikafume 72 jam & 72 jam \\
\hline 3 & BSF IIA1 & Benda uji beton kombinasi & accelerator $1: 3,5+$ sikafume 24 jam & 24 jam \\
\hline 4 & BSF IIA2 & Benda uji beton kombinasi & accelerator $1: 3,5+$ sikafume 72 jam & 72 jam \\
\hline 5 & BSF IIIA1 & Benda uji beton kombinasi & accelerator $1: 5$ + sikafume 24 jam & 24 jam \\
\hline 6 & BSF IIIA2 & Benda uji beton kombinasi & accelerator $1: 5$ + sikafume 72 jam & 72 jam \\
\hline
\end{tabular}

4. Pengujian slump

Pengujian slump test dilakukan menggunakan kerucut ambrams untuk mengetahui tingkat workability (kemudahan dalam pengerjaan) dari campuran beton. Slump beton adalah besaran kekentalan (viscosity) atau plastisitas dan kohesif dari beton segar.

5. Pengujian kuat tekan

Pengujian kekuatan tekan beton dilakukan menggunakan mesin tekan. Hasil massa beban maksimum akan terbaca dalam satuan ton atau $\mathrm{N} / \mathrm{mm}^{2}$. Pembebanan dilakukan secara perlahan sampai beton mengalami kehancuran.

\section{HASIL DAN PEMBAHASAN}

\section{Pengujian Slump Test}

Tabel 3. Hasil Pengujian Slump Setiap Variasi Benda Uji

\begin{tabular}{|c|c|c|c|}
\hline No. & Benda uji & Kode Benda Uji & Nilai slump $(\mathbf{C m})$ \\
\hline 1 & Benda uji beton kombinasi accelerator $1: 2+$ sikafume & BBA1 SF & 27 \\
\hline 2 & Benda uji beton kombinasi accelerator $1: 3,5+$ sikafume & BBA2 SF & 21 \\
\hline 3 & Benda uji beton kombinasi accelerator $1: 5$ + sikafume & BBA3 SF & 18 \\
\hline
\end{tabular}

Hasil pengujian slump yang diperoleh untuk benda uji BSF IA, benda uji BSF IIA dan benda uji BSF IIIA masing-masing sebesar 27, 21 dan $18 \mathrm{~cm}$. Nilai slump yang diperoleh termasuk katagori slump runtuh. Nilai slump yang diperoleh lebih besar dari yang direncanakan dalam mix design, yaitu sebesar 7,5 sampai $12 \mathrm{~cm}$. Hal ini disebabkan karena penggunaan accelerator mengakibatkan kelecakan beton bertambah, karena salah satu sifat dari accelarator dapat meningkatkan kelecakan beton.

\section{Pengujian Kuat Tekan}

Tabel 4. Hasil Pengujian Kuat Tekan untuk Setiap Variasi Benda Uji

\begin{tabular}{|c|c|c|c|c|c|}
\hline No. & & Benda uji & $\begin{array}{c}\text { Kode } \\
\text { Benda Uji }\end{array}$ & $\begin{array}{c}\text { Nilai } \\
\text { Kuat } \\
\text { Tekan } \\
\left(\mathrm{Kg} / \mathrm{Cm}^{2}\right)\end{array}$ & $\begin{array}{c}\text { Nilai } \\
\text { Kuat } \\
\text { Tekan } \\
\text { (Mpa) }\end{array}$ \\
\hline 1 & Benda uji beton kombinasi & accelerator $1: 2$ + sikafume 24 jam & BSF IA 1 & 323,173 & 26,823 \\
\hline 2 & Benda uji beton kombinasi & accelerator $1: 2$ + sikafume 72 jam & BSF IIA2 & 376,863 & 31,280 \\
\hline 3 & Benda uji beton kombinasi & accelerator $1: 3,5+$ sikafume 24 jam & BSF IIA1 & 300,162 & 24,913 \\
\hline 4 & Benda uji beton kombinasi & accelerator $1: 3,5+$ sikafume 72 jam & BSF IIA2 & 369,193 & 30,643 \\
\hline 5 & Benda uji beton kombinasi & accelerator $1: 5$ + sikafume 24 jam & BSF IIIA1 & 284,822 & 23,640 \\
\hline 6 & Benda uji beton kombinasi & accelerator $1: 5$ + sikafume 72 jam & BSF IIIA2 & 365,358 & 30,325 \\
\hline
\end{tabular}

Pengujian kuat tekan beton benda uji BSF IA1, BSF IIA1 dan BSF IIIA1 dilakukan pada saat benda uji berumur 24 jam. Benda uji BSF IA1, BSF IIA1 dan BSF IIIA1 memiliki nilai kuat tekan berturutturut sebesar 26,823 Mpa, 24,913 Mpa dan 23,640 Mpa. Jika dinyatakan dalam persentase, maka nilai 
kuat tekan benda uji BSF IIA1 dan BSF IIIA1 lebih kecil 7,7\% dan 13,46\% dari nilai kuat tekan benda uji BSF IA1. Hal yang serupa terjadi pada pengujian kuat tekan beton benda uji BSF IA2, BSF IIA2 dan BSF IIIA3 yang dilakukan pada saat benda uji berumur 72 jam. Benda uji BSF IA2, BSF IIA2 dan BSF IIIA2 memiliki nilai kuat tekan berturut-turut sebesar 31,280 Mpa, 30,643 Mpa dan 30,325 Mpa. Jika dinyatakan dalam persentase, maka nilai kuat tekan benda uji BSF IIA2 dan BSF IIIA2 lebih kecil 2,07\% dan 2,16\% dari nilai kuat tekan benda uji BSF IA2.

Dosis penggunaan accelerator yang paling besar hingga yang paling kecil berturut turut adalah benda uji BSF IA (1:2), BSF IIA (1:3,5) dan BSF IIIA (1:5). Dari tabel 2 di atas, diketahui bahwa variasi dosis penggunaan accelerator mempengaruhi perolehan hasil pengujian kuat tekan beton. Semakin besar dosis penggunaan accelerator, maka nilai kuat tekan yang diperoleh semakin besar. Hal ini terjadi pada setiap variasi umur pengujian baik 24 jam maupun 72 jam. Sehingga, variasi dosis penggunaan accelerator sangat mempengaruhi waktu perkerasan benda uji yang berdampak terhadap besar kecilnya nilai kuat tekan beton yang dihasilkan pada setiap umur pengujian.

Penggunaan kombinasi bahan silicafume (additive) dan accelerator (admixture) dapat mencapai kekuatan mutu beton struktural (mutu rencana K-300) dalam waktu singkat (24-72 jam). Maka, hasil penelitian menunjukkan bahwa setelah benda uji berumur 72 jam ( 3 hari) nilai kuat tekan beton yang dihasilkan untuk ketiga kelompok variasi benda uji (variasi dosis penggunaan accelerator) memiliki nilai kuat tekan rata-rata di atas 24,90 Mpa (K-300). Hal ini juga terjadi pada hasil pengujian kuat tekan pada umur $24 \mathrm{jam}$. Dimana nilai kuat tekan yang diperoleh mencapai mutu $300 \mathrm{Kg} / \mathrm{cm}^{2}$ atau 24,90 Mpa. Hanya pada dosis penggunaan accelerator 1:5 saja (benda uji BSF IIIA1) yang memiliki nilai kuat tekan di bawah $300 \mathrm{Kg} / \mathrm{cm} 2$ atau 24,90 Mpa.

\section{SIMPULAN}

Berdasarkan hasil dan pembahasan penelitian terkait dengan nilai kuat tekan beton, maupun bentuk atau workability dan waktu perkerasan adalah sebagai berikut: 1) hasil uji kuat tekan beton kombinasi sikafume dengan variasi dosis penggunaan accelerator 1:2 memiliki nilai kuat tekan rata-rata sebesar 26,823 Mpa dan 31,280 Mpa untuk umur pengujian 24 dan 72 jam; 2) hasil uji kuat tekan beton kombinasi sikafume dengan variasi dosis penggunaan accelerator 1:3,5 memiliki nilai kuat tekan ratarata sebesar 24,913 Mpa dan 30,643 Mpa untuk umur pengujian 24 dan 72 jam; 3) hasil uji kuat tekan beton kombinasi sikafume dengan variasi dosis penggunaan accelerator 1:5 memiliki nilai kuat tekan rata-rata sebesar 23,640 Mpa dan 30,325 Mpa untuk umur pengujian 24 dan 72 jam; 4) nilai slump yang diperoleh pada setiap variasi benda uji lebih besar dari yang direncanakan dalam mix design, yaitu nilai slump yang diperoleh termasuk katagori slump runtuh; dan 5) kombinasi sikafume dan variasi dosis accelerator dapat mempercepat waktu perkerasan dengan nilai kuat tekan rata-rata di atas 24,90 Mpa atau K-300 dalam waktu 24 dan 72 jam.

\section{REFERENSI}

ASTM, Standard. 2004. Annual Book of American Society for Testing and Materials Standard. New York, USA.

Badan Standarisasi Nasional. 1989. Tata Cara Pelaksanaan Lapis Aspal Beton (Laston) (SNI 1737-1989F). Jakarta: Badan Standarisasi Nasional. 2008. Cara Uji Slump Beton (SNI 1972-2008). Jakarta: BSN. 1993. Tata Cara Pembuatan Rencana Campuran Beton Normal (SNI 032834). Jakarta: BSN.

2002. Tata Cara Perencanaan Struktur Beton untuk Bangunan Gedung (SNI 03 - 2847 - 2002). Bandung: BSN. 
Helmy, Dharmawan. 2018. Studi Penggunaan Sikagrout dan Accelerator Terhadap Kuat Tekan serta Percepatan Perkerasan Beton (Tugas Akhir). Bireuen: Program Studi Teknik Sipil, Fakultas Teknik Universitas Almuslim.

Murdock, L.J., K.M, Brook. 1999. Bahan dan Praktek Beton (terj. Stephanus Hendarko). Jakarta: Erlangga.

Nawy, E.G. 1990. Reinforce Concrete a fundamental Approch (terj.) Bandung: Prentice Hall.

Subakti, A. 1995. Teknologi Beton dalam Praktek. Surabaya: Laboratorium Jurusan Teknik Sipil ITS. 